\title{
Pengaruh Model Pembelajaran BCCT dan Kemandirian Terhadap Kreativitas Bermain Balok Anak Usia 4-6 Tahun di Kecamatan Ciracas 2012
}

\author{
Sri Mundariyah \\ (Program studi PG-PAUD, Fakultas Ilmu Pendidikan Universitas MH. Thamrin)
}

\begin{abstract}
ABSTRAK
Tujuan penelitian ini adalah untuk mencari bukti empiris tentang pengaruh model pembelajaran dan kemandirian terhadap kreativitas bermain balok. Pada penelitian ini metode penelitian yang digunakan adalah metode eksperimen. Responden penelitian adalah anak usia 4-6 tahun di kecamatan Ciracas sebanyak 44 anak yang dipilih secara acak sederhana dari jumlah siswa keseluruhan 115 orang. Teknik pengumpulan data menggunakan untuk instrumen kreativitas bermain balok adalah pengamatan dan instrumen kemandirian adalah dengan angket. Instrumen dikalibrasi dengan memakai uji validitas butir dan koefisien reliabilitas. Validitas butir dihitung dengan memakai koefisien korelasi product moment, sedangkan koefisien reliabilitas instrument dihitung dengan rumus Alpha Cronbach untuk instrumen kemandirian dan Hyot untuk instrumen kreativitas bermain balok. Persyaratan analisis data diuji dengan normalitas populasi (uji Liliefors) dan dengan homogenitas varians populasi (uji Barlett). Analisis data menggunakan annava dua jalur. Hasil penelitian ini adalah sebagai berikut: (1) kreativitas anak yang diberi model pembelajaran BCCT lebih tinggi daripada anak yang diberi model pembelajaran konvensional. Dari gambaran ini dapat dikatakan bahwa untuk meningkatkan kreativitas anak usia dini dapat digunakan model pembelajaran BCCT; (2) Kreativitas anak yang diberi model pembelajaran BCCT pada kelompok siswa yang memiliki kemandirian tinggi lebih tinggi daripada kelompok siswa yang diberi model pembelajaran konvensional. Dengan demikian untuk meningkatkan kreativitas anak usia dini yang memiliki kemandirian tinggi dapat menggunakan model pembelajaran BCCT(3) Kreativitas anak yang diberi model pembelajaran konvensional pada kelompok siswa kemandirian rendah lebih tinggi daripada kelompok siswa yang diberi model pembelajaran BCCT. Dengan demikian untuk meningkatkan kreativitas anak usia dini yang memiliki kemandirian rendah dapat digunakan model pembelajaran konvensional; (4) Terdapat interaksi antara model pembelajaran dan kemandirian terhadap kreativitas bermain balok anak usia dini.
\end{abstract}




\section{PENDAHULUAN}

Kreativitas merupakan salah satu factor yang menentukan terwujudnya sikap, pola pikir dan perilaku kreatif dari seseorang. Kreativitas adalah kemampuan yang mencerminkan kelancaran, keluwesan (fleksibitas), dan orisinalitas dalam berfikir, serta kemampuan untuk mengelaborasi (mengembangkan, memperkaya, memperinci ) suatu gagasan. ${ }^{1}$ Kemampuan tersebut dapat memberikan manfaat besar bagi kehidupan manusia apabila dipupuk dan dikembangkan sejak usia dini.

Pola pikir dan perilaku kreatif sangat penting ditanamkan dalam diri anak sejak usia dini. Pada dasarnya setiap anak dilahirkan dengan bakat kreatif tertentu yang dimilikinya. Bakat kreatif tersebut perlu dikenali, dipupuk dan dikembangkan melalui stimulasi yang tepat agar kreativitas anak dapat terwujud, karena ekspresi tertinggi dari keberbakatan adalah kreatifitas. ${ }^{2}$

Pendidikan merupakan salah satu upaya mewujudkan dan mengoptimalkan berbagai potensi anak termasuk kreativitas. Pendidikan dapat terjadi dalam lingkungan keluarga, sekolah, dan masyarakat. Ketiga lingkungan pendidikan tersebut sangat mempengaruhi tumbuhnya kreativitas dalam diri anak. Menurut Undang-ndang No.20 tahun 2003 ayat 2 sampai ayat 5 terdapat 3 jalur pendidikan anak usia dini yaitu, Jlur formal berbentuk Taman Kanak- Kanak dan Roudhatul Atfal, jalur non formal atau luar sekolah dibawah Subdit Satuan PAUD Sejenis berbentuk Kelompok Bermain (KB), Tempat Penitipan Anak (TPA), dan atau bentuk lain yang sederajat, dan jalur informal yaitu berbentuk Pendidikan Keluarga atau pendidikan lingkungan. ${ }^{3}$ Berdasarkan Undang-Undang diatas, maka Taman Asuh Anak Muslim (TAAM) termasuk kedalam salah satu penyelenggaraan Pendidikan Anak Usia Dini yang berada di jalur luar sekolah atau nonformal.

Pada dasarnya Taman Asuh Anak Muslim (TAAM) merupakan salah satu wadah yang didirikan untuk menyelenggarakan berbagai kegiatan-kegiatan anak yang dapat merangsang daya kreativitas melalui bermain. Dengan menggunakan model "Beyond Centres and Circles Time "(BCCT) atau pendekatan" Sentra dan Saat Lingkaran" telah teruji keandalannya di banyak Negara. ${ }^{4}$ Penggunaan pendekatan BCCT dimaksudkan untuk diterapkan dalam penyelenggaraan Satuan PAUD Sejenis (SPS) termasuk TAAM. Melalui model pendekatan BCCT, anak dilatih dan dirangsang untuk mengembangkan daya imajinasi dan kreativitasnya. Oleh karena itu selain membekali anak dengan kegiatan bermain kreatif diharapkan bakat kreatif yang ada dalam diri anak dapat melejit dan berkembang dengan baik

\section{KAJIAN TEORITIK \\ Pengertian Kreativitas}

Kreativitas adalah salah satu kemampuan atau potensi yang ada dalam diri setiap manusia. Pada dasarnya setiap anak atau individu memilki bakat kreatif. Bakat ini perlu dirangsang dan diberi arahan yang tepat, karena bakat kreatif seseorang seseorang dapat hilang atau tidak terwujud akibat kurangnya stimulasi. Oleh karna itu kreatifitas merupakan salah satu potensi didalam diri individu yang penting untuk diperhatikan munandar mendevinisikan pengertian kreatifitas secara operasional yang berarti "Kemampuan yang mencermikan kelancaran,kelulusan (fleksibilatas) dan orisinalitas dalam berfikir serta kemampuan untuk mengelaborasi (mengembangkan, memperkaya,memerinci) suatu gagasan. ${ }^{5}$ Pendapat tersebut merumuskan kreatifitas sebagai suatu kemampuan berfikir yang orisinal,dan mampu menggabungkan bahkan memperkaya suatu gagasan menjadi sutu produk baru. Kreatifitas adalah suatu

\footnotetext{
${ }^{1}$ Utami Munandar, Mengembangkan Bakat Dan Kreativitas Anak Sekolah : Petunjuk bagi Orang Tua \& Guru (Jakarta: PT.Gramedia), h.50.

2 Conny R. Semiawan, Belajar dan Pembelajaran Dalam Pendidikan Anak Usia Dini : Pendidikan Prasekolah dan Dasar (Jakarta : PT.Prenhalindo,2002), h.126.

3 Pendidikang-Undang No. 20 Tah

4 Tim LPPKS-BKPRMI, “Buku Panduan Taman Asuh Anak Muslim”, (Surabaya, Sekretariat BKPRMI Jawa Timur, 2007), h.1

${ }^{5}$ S.C. Utami Munandar, Mengembangkan Bakat dan Kreatifitas Anak Sekolah: Petunjuk Bagi Orangtua dan Guru (Jakarta: PT Gramedia Widiasarana Indonesia,1992),h.50
} 
pola fikir yang mendorong seseorang untuk senintiasa mencari dan menghasilkan ide-ide baru kreatifitas seringkali dipandang sebagai suatu produk yaitu hasil dari pemikiran atau peri laku manusia.

\section{Pengertian Bermain}

Bermain merupakan suatu kegiatan yang menyenangkan dan dilakukan dengan suka rela. Bermain adalah suatu kegiatan yang dilakukan dengan atau tanpa mempergunakan alat yang menghasilkan pengertian atau memberikan informasi , memberi kesenangan dan mengembangkan imajinasi pada anak. ${ }^{6}$ Bermain merupalan suatu kegiatan yang digunakan sebagai media untuk meningkan ketrampilan dan kemampuan tertentu pada anak, serta memberikan kesenangan pada anak. . Menurut Hurlock bermain adalah setiap kegiatan yang dilakukan untuk kesenangan yang ditimbulkan tanpa mempertimbangkan hasil akhir. ${ }^{7}$ Bermain merupakan kegiatan tanpa memikirkan hasil akhir dari kegiatan itu sendiri. Selanjutnya Hurlock mengemukakan bahwa bermain berbeda dengan bekerja, karena ketika bekerja seseorang memikirkan hasil akhir dari yang dikerjakan, bekerja juga tidak mengharuskan seseorang yang bersangkutan merasa senang.

\section{Pengertian BCCT}

Beyond Centres and Circle Time atau pendekatan sentra dan saat lingkaran diadopsi dari Creative Center for Childhood Research and Training (CCRT) yang dipelopori oleh DR.Pamella yang berkedudukan di Florida, Amerika Serikat. Model ini dimaksudkan untuk memperbaiki praktek penyelenggaraan Pendidikan Anak Usia Dini yang masih banyak terjadi salah kaprah. ${ }^{8}$ Pengertian Beyond Centers ang Circle Time adalah :Beyond Centers and Circle Time is a play-based curriculum designed to provide caregives with explicit ideas for creating loving, playfull, and stimulating experiences for young children age birth through kindergarten. This curriculum has been practiced and perfected through over 30 years of use by the staf and children of The Creative Pre-School located in Tallahasse, Florida. ${ }^{9}$ Pernyataan di atas menjelaskan bahwa pendekatan sentra dan saat lingkaran adalah basis kurikulum permainan yang dirancang untuk memberi kelengkapan dengan ide-ide yang tegas untuk berkreasi dengan penuh penuh kasih sayang, kesenangan bermain, dan Saat Lingkaran merangsang pengalaman-pengalaman anak usia Taman Kanak-kanak. Kurikulum ini sangat praktis dan sempurna, dan telah dipraktekkan lebih dari 30 tahun oleh pengajar-pengajar dan siswa-siswa pra-sekolah di Tallahasse, Florida.

\section{Pengertian Kemandirian}

Kemandirian berasal dari kata mandiri yang berarti keadaan dapat berdiri sendiri, tidak tergantung pada orang lain. Hurlock berpendapat bahwa kemandirian adalah mampu menerima tanggung jawab sendiri, bebas dalam berfikir dan bertindak, mampu mengatur dan menentukan jalan hidupnya dalam memenuhi keinginan dan kebutuhan hidupnya. ${ }^{10} \mathrm{Hal}$ ini menyatakan bahwa pribadi yang mandiri merupakan pribadi yang bertanggungjawab akan setiap tindakan yang dilakukannya serta mampu mengorganisasi setiap hal yang dilakukannya dalarangka memenuhi kebutuhan hidupnya yang dilakukan secara bebas. Sejalan dengan pendapat Hurlock tersebut, Gilmore menyatakan bahwa kemandirian itu adalah bersikap dan berlaku mandiri sebagai kebebasan seseorang dari pengaruh dan pengawasan dari orang lain. ${ }^{11}$

\section{Karakteristik Kemandirian Anak Usia 4-6 Tahun.}

Karakteristik perkembangan kemandirian tidak terlepas dari tahapan perkembangan manusia. Pada dasarnya perkembangan kemandirian dipengaruhi oleh tahapan perkembangan anak. Salah satu pendapat mengenai karakteristik perkembangan kemandirian anak usia 4-6 tahun diungkapkan oleh Lindberg dan

\footnotetext{
${ }^{6}$ Anggani Sudono, Sumber Belajar dan Alat Permainan (Jakarta: Grasindo, 2000), h.1

${ }^{7}$ Elizabeth B. Hurlock, Perkembangan Anak jilid I ( Jakarta: Erlangga, h.320

${ }^{8}$ Dirjen PLS dan Direktorat PAUD, Pedoman Teknis Penyelenggaran POS PAUD,(Jakarta: Departemen Pendidikan Nasional, 2006),hlm.2

${ }^{9}$ The Creative Center for Childhood Recearch and Training, Inc.(CCCRT)

${ }^{10}$ Elizabeth B. Hurlock, Personality Development (New Delhi : McGraw Hill, 1974), h.428

${ }^{11}$ John V. Gilmore, The Productive Perality (California: Albion Publishing Company, 1974), h.155
} 
Swedlow. Menurut Lindberg dan Swedlow, anak belajar untuk memecahkan masalah yang dihadapi dan dapat bekerjasama dengan teman dan orang dewasa. ${ }^{12}$.

\section{Hipotesis Penelitian}

Berdasarkan deskripsi teoritis dan kerangka berfikir, maka hipotesis dari penelitian ini adalah:

1. Secara keseluruhan kreativitas bermain balok anak yang menggunakan model pembelajaran BCCT lebih tinggi dari pada anak yang menggunakan model pembelajaran konvensional.

2. Terdapat interaksi antara model pembelajaran BCCT dan kemandirian terhadap kreativitas bermain balok.

3. Untuk kelompok anak yang memiliki kemandirian tinggi kreativitas bermain balok lebih tinggi menggunakan model pembelajaran BCCT dibandingkan dengan siswa yang menggunakan model pembelajaran konvensional.

4. Untuk kelompok siswa yang memiliki kemandirian rendah kreativitas bermain baloknya lebih tinggi menggunakan model pembelajaran konvensional dibandingkan dengan anak yang menggunakan model pembelajaran BCCT.

\section{Metode Penelitian}

Penelitian ini menggunakan metode Eksperimen dengan desain factorial 2 x 2 sebagai berikut:

Tabel

Desain Rancangan Faktorial 2x2

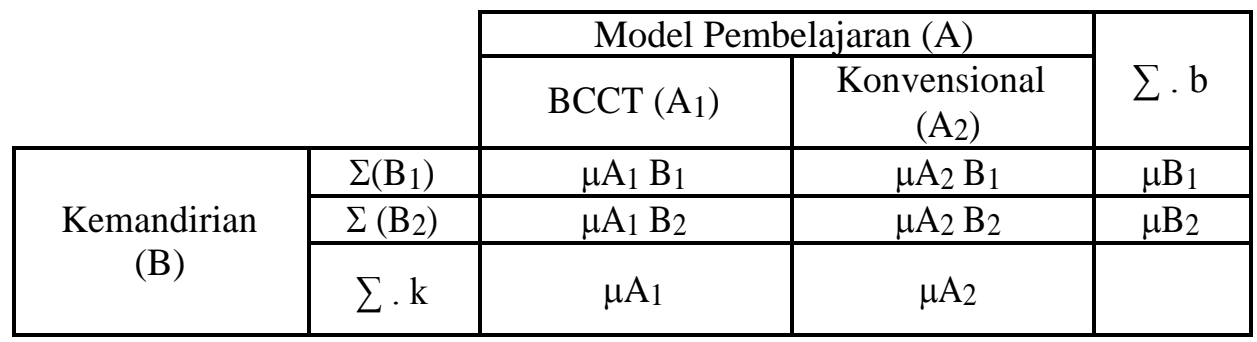

Keterangan :

A1 : kelompok siswa yang menerima model pembelajaran BCCT

$\mathrm{A}_{2} \quad$ : Kelompok siswa yang menerima model pembelajaran konvensional.

$\mathrm{A}_{1} \mathrm{~B}_{1}$ : kelompok siswa yang menggunakan model pembelajaran BCCT memiliki kemandirian tinggi.

$\mathrm{A}_{2} \mathrm{~B}_{1}$ : kelompok siswa yang menerima model pembelajaran konvensional dan memiliki kemandirian tinggi.

$\mathrm{A}_{1} \mathrm{~B}_{2}$ : kelompok siswa yang menggunakan model pembelajaran $\mathrm{BCCT}$ dan memiliki kemandirian rendah

$\mathrm{A}_{2} \mathrm{~B}_{2}$ : kelompok siswa yang menerima model pembelajaran konvensional dan memiliki kemandirian rendah.

\section{Populasi dan Sampel}

\section{Populasi}

Adapun populasi dari penelitian ini adalah seluruh siswa Taman Asuh Anak Muslim Nurul Hidayah

Kecamatan Ciracas, Jakarta Timur. Peneliti mengambil TAAM Nurul Hidayah sebagai populasi

\footnotetext{
${ }^{12}$ Jeffry S. Turner, Donald B.Helms, Life-Spam Development (USA : Rinehart and Winston Inc, 1995), h.233
}

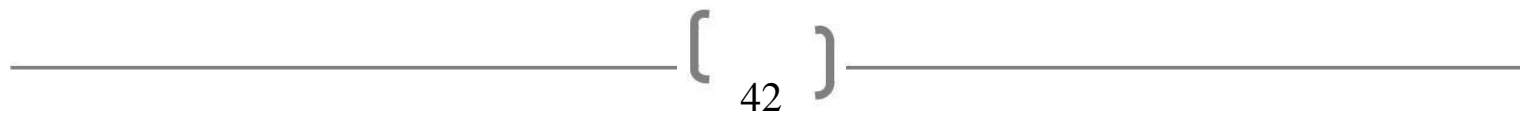




\section{Sampel}

Sampel dalam penelitian ini adalah siswa Taman Asuh Anak Muslim (TAAM) Nurul Hidayah yang berjumlah 44 orang dari jumlah siswa keseluruhan 115 orang. Pada penelitian ini sampel yang diambil untuk mewakili populasi menggunakan teknik purposive sampling, yaitu teknik sampling yang digunakan oleh peneliti jika peneliti mempunyai pertimbangan-pertimbangan tertentu dalam mengambil sampelnya. ${ }^{13}$ Pada penelitian ini peneliti mengambil sampel sebanyak 44 anak dari dua kelas yang dipilih, di mana masing-masing kelas terdiri dari 22 anak.

\section{HASIL DAN PEMBAHASAN}

\section{Kreativitas bermain balok anak yang Diberikan Model pembelajaran BCCT (A1)}

Data kreativitas bermain balok anak bagi kelompok yang diberikan model pembelajaran BCCT, secara teoretik skor minimum yang dapat dicapai adalah 18 dan skor maksimum adalah 72 . Berdasarkan tes kreativitas bermain balok anak yang diujikan kepada 22 anak yang diberi model pembelajaran BCCT, diperoleh skor maksimum 56, skor minimum 38, skor rata-rata 46,86 standar deviasi 6,02. Dari skor maksimum dan minimum tersebut, diperoleh rentangan skor 18, interval kelas 4 dan banyaknya kelas 5 . Dari data tersebut dapat ditampilkan dalam bentuk tabel berikut ini:

Tabel

Tabel Deskripsi Data A1

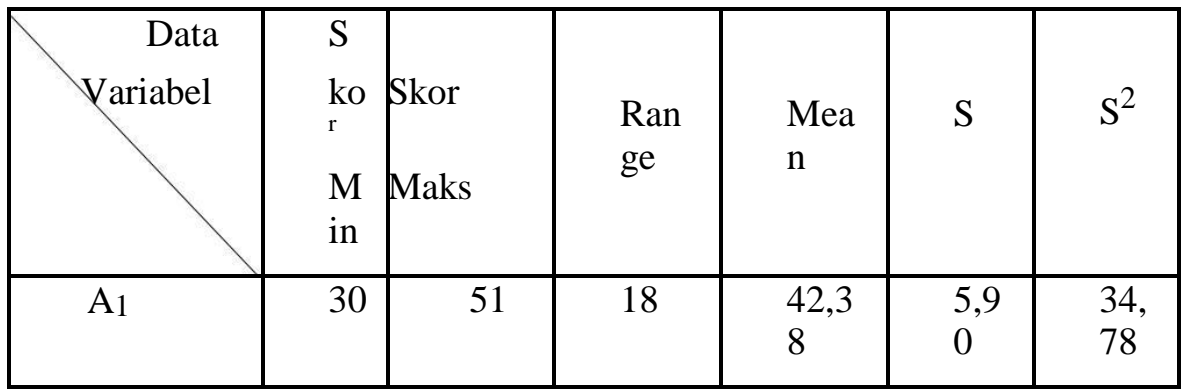

Tabel

Distribusi Frekuensi Skor Kreativitas bermain balok Anak yang Diberikan Model pembelajaran $\mathrm{BCCT}$

\begin{tabular}{|c|c|c|c|c|c|}
\hline Kelas & Batas Kelas & \multicolumn{4}{|c|}{ Frekuensi } \\
\cline { 3 - 6 } Interval & & Absolut & Komulatif (S) & Relatif (\%) & Relatif-Kum \\
\hline $38-41$ & $37.5-41.5$ & 6 & 6 & 27.3 & 27.3 \\
$42-45$ & $41.5-45.5$ & 5 & 11 & 22.7 & 50.0 \\
$46-49$ & $45.5-49.5$ & 1 & 12 & 4.5 & 54.5 \\
$50-53$ & $49.5-43.5$ & 6 & 18 & 27.3 & 81.8 \\
$54-57$ & $50.5-57.5$ & 4 & 22 & 18.2 & 100.0 \\
\hline Jumlah & & 22 & & 100 & \\
\hline
\end{tabular}

${ }^{13}$ Ibid; h...226 


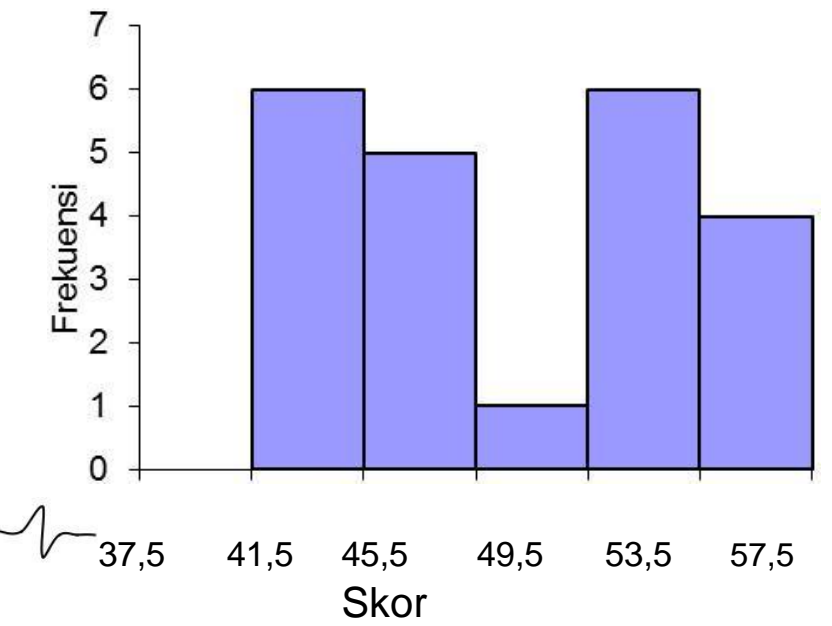

Gambar

Histogram Skor Kreativitas bermain balok anak yang Diberikan Model pembelajaran BCCT

\section{Kreativitas bermain balok anak yang Diberikan Model pembelajaran Konvensional (A2)}

Data kreativitas bermain balok anak kelompok anak yang diberikan model pembelajaran konvensional, secara teoretik skor minimum yang dicapai adalah 18 dan skor maksimum adalah 72 . Berdasarkan kreativitas bermain balok anak yang diujikan kepada 22 anak yang diberi model pembelajaran konvensional, diperoleh skor maksimum 51, skor minimum 37, rata-rata hitung 43,82, standar deviasi 4,33, dan varians 18,73. Dari skor maksimum dan minimum tersebut, diperoleh rentangan skor 14, interval kelas 3 dan banyaknya kelas 5. Dari data tersebut dapat ditampilkan dalam bentuk tabel berikut ini:

Tabel

Deskripsi Data $\mathrm{A}_{2}$

\begin{tabular}{|l|l|l|l|l|l|l|}
\hline $\begin{array}{c}\text { Data } \\
\text { Variabel }\end{array}$ & $\begin{array}{l}\text { S } \\
\text { ko }\end{array}$ & Skor & Ran & & & \\
& $\begin{array}{l}\text { M } \\
\text { in }\end{array}$ & Maks & Mean & S & $\mathrm{S}^{2}$ \\
\hline A2 & 37 & 51 & 14 & 43,82 & $\begin{array}{l}4,3 \\
3\end{array}$ & 18, \\
\hline
\end{tabular}


Tabel

Distribusi Frekuensi Skor Kreativitas bermain balok anak yang Diberikan Model pembelajaran konvensional

\begin{tabular}{|c|c|c|c|c|c|}
\hline \multirow{2}{*}{$\begin{array}{c}\text { Kelas } \\
\text { Interval }\end{array}$} & Batas Kelas & \multicolumn{4}{|c|}{ Frekuensi } \\
\cline { 3 - 6 } & & Absolut & Komulatif (S) & Relatif (\%) & Relatif-Kum \\
\hline $37-39$ & $36.5-39.5$ & 5 & 5 & 22.7 & 22.7 \\
$40-42$ & $39.5-42.5$ & 3 & 8 & 13.6 & 36.4 \\
$43-45$ & $42.5-45.5$ & 5 & 13 & 22.7 & 59.1 \\
$46-48$ & $45.5-48.5$ & 6 & 19 & 27.3 & 86.4 \\
$49-51$ & $48.5-51.5$ & 3 & 22 & 13.6 & 100.0 \\
\hline Jumlah & & 22 & & 100 & \\
\hline
\end{tabular}

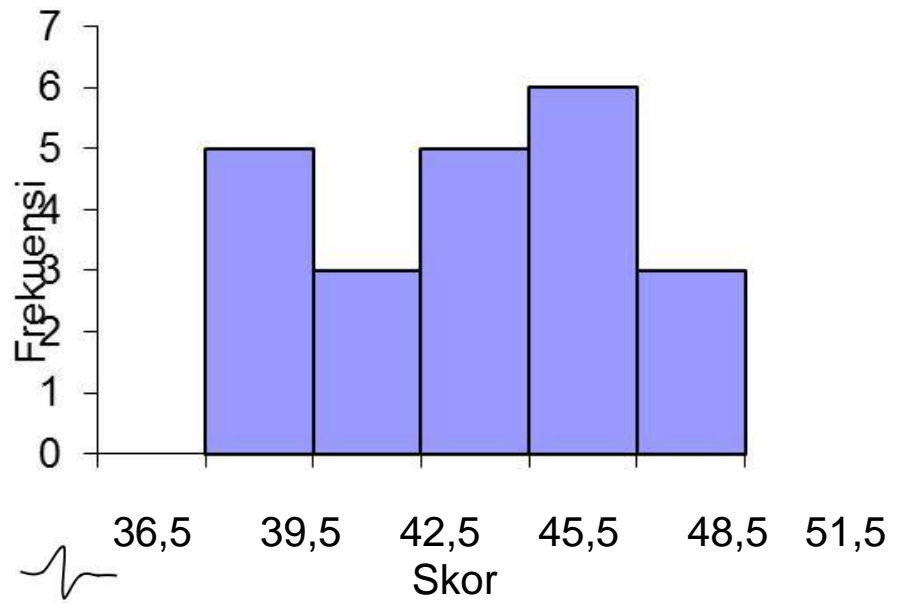

Gambar

Histogram Skor Kreativitas bermain balok anak yang Diberikan Model pembelajaran konvensional

\section{Kreativitas bermain balok Anak yang memiliki kemandirian tinggi}

Data kreativitas bermain balok anak kelompok anak yang diberikan yang memiliki kemandirian tinggi, secara teoretik skor minimum yang dicapai adalah 18 dan skor maksimum adalah 72 . Berdasarkan kreativitas bermain balok anak yang diujikan kepada 22 anak yang diberi model pembelajaran konvensional, diperoleh skor maksimum 56, skor minimum 37, rata-rata hitung 46,27, standar deviasi 6,64, dan varians 44,11. Dari skor maksimum dan minimum tersebut, diperoleh rentangan skor 19, interval kelas 4 dan banyaknya kelas 5. Dari data tersebut dapat ditampilkan dalam bentuk tabel berikut ini:

Tabel

Deskripsi Data B1

\begin{tabular}{|l|l|l|l|l|l|l|}
\hline $\begin{array}{l}\text { Data } \\
\text { Variabel }\end{array}$ & $\begin{array}{l}\text { S } \\
\text { ko } \\
\text { r } \\
\text { M } \\
\text { in }\end{array}$ & Maks & $\begin{array}{l}\text { Ran } \\
\text { ge }\end{array}$ & Mean & S & $S^{2}$ \\
\hline A2 & 37 & 56 & 19 & 46,27 & $\begin{array}{l}6,6 \\
4\end{array}$ & $\begin{array}{l}44, \\
11\end{array}$ \\
\hline
\end{tabular}


Dengan data tersebut, dibuat tabel distribusi frekuensi kreativitas bermain balok anak untuk yang diberikan model pembelajaran konvensional, seperti pada Tabel.

Tabel

Distribusi Frekuensi Skor Kreativitas bermain balok anak yang memiliki kemandirian tinggi

\begin{tabular}{|c|c|c|c|c|c|}
\hline Kelas & Batas Kelas & \multicolumn{4}{|c|}{ Frekuensi } \\
\cline { 3 - 6 } Interval & & Absolut & Komulatif (S) & Relatif (\%) & Relatif-Kum \\
\hline $37-40$ & $36.5-40.5$ & 4 & 4 & 18.2 & 18.2 \\
$41-44$ & $40.5-44.5$ & 5 & 9 & 22.7 & 40.9 \\
$45-48$ & $44.5-48.5$ & 2 & 11 & 9.1 & 50.0 \\
$49-52$ & $48.5-52.5$ & 6 & 17 & 27.3 & 77.3 \\
$53-56$ & $52.5-56.5$ & 5 & 22 & 22.7 & 100.0 \\
\hline Jumlah & & 22 & & 100 & \\
\hline
\end{tabular}

Agar lebih jelas maka dibuat histogram sebagai berikut :

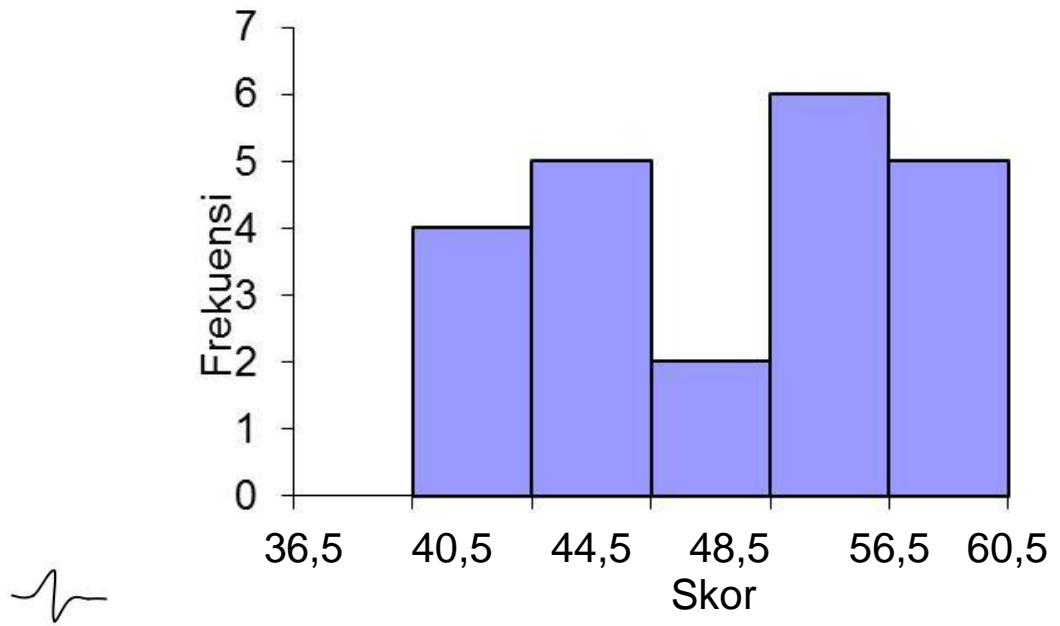

Gambar

Histogram Skor Kreativitas bermain balok anak yang memiliki kemandirian tinggi

\section{Kreativitas bermain balok Anak yang memiliki kemandirian rendah}

Data kreativitas bermain balok anak kelompok anak yang diberikan yang memiliki kemandirian rendah, secara teoretik skor minimum yang dicapai adalah 18 dan skor maksimum adalah 72 . Berdasarkan kreativitas bermain balok anak yang diujikan kepada 22 anak yang memiliki kemandirian rendah, diperoleh skor maksimum 51, skor minimum 38, rata-rata hitung 44,41, standar deviasi 3,72, dan varians 13,87. Dari skor maksimum dan minimum tersebut, diperoleh rentangan skor 13, interval kelas 3 dan banyaknya kelas 5. Dari data tersebut dapat ditampilkan dalam bentuk tabel berikut ini: 
Tabel

Deskripsi Data $\mathrm{B}_{2}$

\begin{tabular}{|l|l|l|l|l|l|l|}
\hline Variabel & $\begin{array}{l}\text { S } \\
\text { ko } \\
\text { r } \\
\text { M } \\
\text { in }\end{array}$ & Maks & $\begin{array}{l}\text { Ran } \\
\text { ge }\end{array}$ & Mean & S & $\mathrm{S}_{2}$ \\
\hline $\mathrm{A}_{2}$ & 38 & 51 & 13 & 44,41 & $\begin{array}{l}3,7 \\
2\end{array}$ & $\begin{array}{l}13, \\
87\end{array}$ \\
\hline
\end{tabular}

Dengan data tersebut, dibuat tabel distribusi frekuensi kreativitas bermain balok anak untuk yang diberikan model pembelajaran konvensional, seperti pada Tabel 9.

Tabel

Distribusi Frekuensi Skor Kreativitas bermain balok anak yang memiliki kemandirian rendah

\begin{tabular}{|c|c|c|c|c|c|}
\hline Kelas & Batas Kelas & \multicolumn{4}{|c|}{ Frekuensi } \\
\cline { 3 - 6 } Interval & & Absolut & Komulatif (S) & Relatif (\%) & Relatif-Kum \\
\hline $38-40$ & $37.5-40.5$ & 4 & 4 & 18.2 & 18.2 \\
$41-43$ & $40.5-43.5$ & 5 & 9 & 22.7 & 40.9 \\
$44-46$ & $43.5-46.5$ & 5 & 14 & 22.7 & 63.6 \\
$47-49$ & $46.5-49.5$ & 6 & 20 & 27.3 & 90.9 \\
$50-52$ & $49.5-52.5$ & 2 & 22 & 9.1 & 100.0 \\
\hline Jumlah & & 22 & & 100 & \\
\hline
\end{tabular}

Agar lebih jelas maka dibuat histogram sebagai berikut :

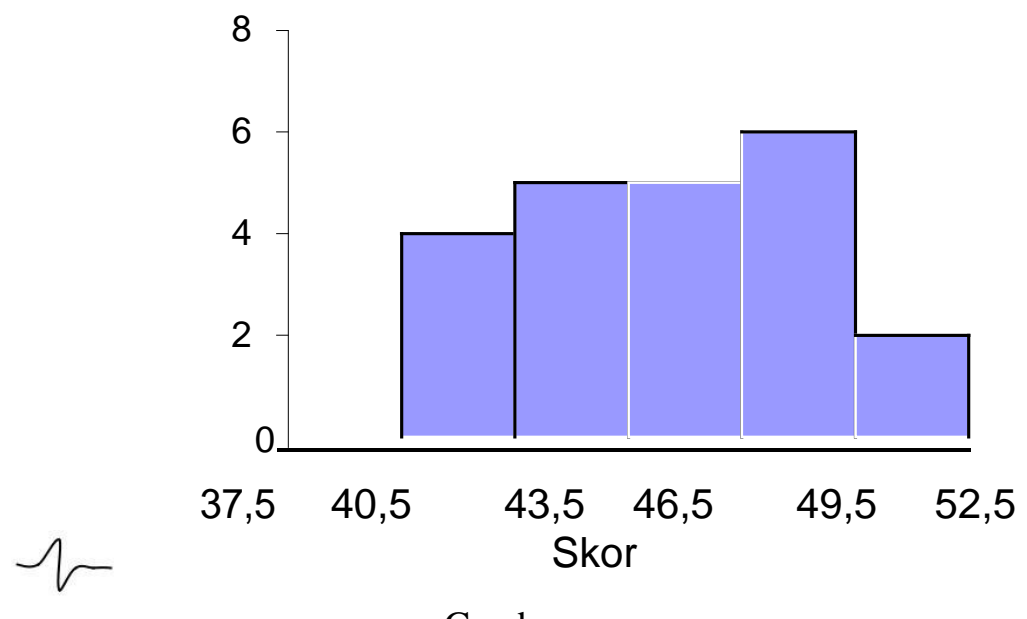

Gambar

Histogram Skor Kreativitas bermain balok anak yang memiliki kemandirian rendah 


\section{Kreativitas bermain balok Anak yang Diberikan Model pembelajaran BCCT dengan}

Kemandirian Tinggi (A1 $\left.\mathrm{B}_{1}\right)$

Data kreativitas bermain balok anak kelompok yang diberikan model pembelajaran BCCT dengan kemandirian tinggi, secara teoretik skor minimum yang dicapai adalah 18 dan skor maksimum adalah 72. Berdasarkan tes kreativitas bermain balok anak yang diujikan kepada 11 anak yang diberikan model pembelajaran BCCT dan memiliki kemandirian tinggi, diperoleh skor maksimum 56, skor minimum 49, rata-rata hitung 52,36; standar deviasi 2,25; dan varians 5,05;. Dari skor maksimum dan minimum tersebut, diperoleh rentangan skor 7, interval kelas 2 dan banyaknya kelas 4. Dari data tersebut dapat ditampilkan dalam bentuk tabel berikut ini:

Tabel

Deskripsi Data $\mathrm{A}_{1} \mathrm{~B}_{1}$

\begin{tabular}{|l|l|l|l|l|l|l|}
\hline $\begin{array}{r}\text { Data } \\
\text { Variabel }\end{array}$ & $\begin{array}{l}\text { S } \\
\text { ko } \\
\text { r }\end{array}$ & Skor \\
& $\begin{array}{l}\text { M } \\
\text { in }\end{array}$ & $\begin{array}{l}\text { Raks } \\
\text { ge }\end{array}$ & $\begin{array}{l}\text { Me } \\
\text { an }\end{array}$ & S & $S^{2}$ \\
\hline $\mathrm{A}_{1} \mathrm{~B}_{1}$ & 49 & 56 & 7 & $\begin{array}{l}52, \\
36\end{array}$ & $\begin{array}{l}2,2 \\
5\end{array}$ & $\begin{array}{l}5,0 \\
5\end{array}$ \\
\hline
\end{tabular}

Dengan data tersebut, dapat dibuat tabel distribusi frekuensi, seperti tampak pada Tabel 15.

Tabel

Distribusi Frekuensi Skor Kreativitas bermain balok Anak yang Diberikan Model pembelajaran BCCT dengan Kemandirian Tinggi

\begin{tabular}{|c|c|c|c|c|c|}
\hline Kelas & Batas Kelas & \multicolumn{4}{|c|}{ Frekuensi } \\
\cline { 3 - 6 } Interval & & Absolut & Komulatif (S) & Relatif (\%) & Relatif-Kum \\
\hline $49-50$ & $48.5-50.5$ & 3 & 3 & 27.3 & 27.3 \\
$51-52$ & $50.5-52.5$ & 3 & 6 & 27.3 & 54.5 \\
$53-54$ & $52.5-54.5$ & 3 & 9 & 27.3 & 81.8 \\
$55-56$ & $54.5-56.5$ & 2 & 11 & 18.2 & 100.0 \\
\hline Jumlah & & 11 & & 100 & \\
\hline
\end{tabular}


Agar lebih jelas maka dibuat histogram sebagai berikut :

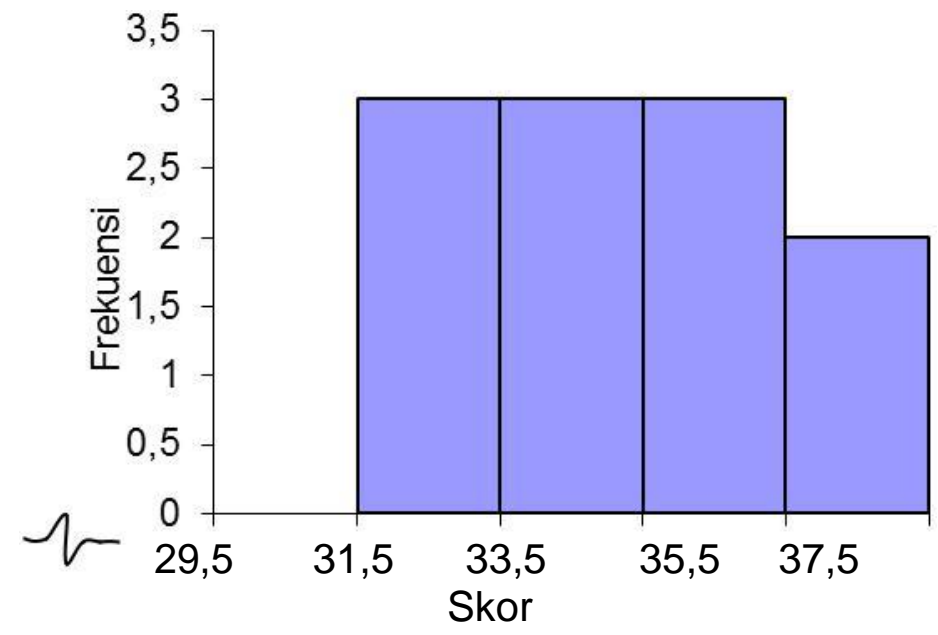

Gambar

Histogram Skor Kreativitas bermain balok Anak dengan Kemandirian Tinggi yang Diberikan Model pembelajaran BCCT

\section{Kreativitas bermain balok anak dengan Kemandirian Rendah yang Diberikan Model} pembelajaran BCCT $\left(\mathrm{A}_{1} \mathrm{~B}_{2}\right)$

Data kreativitas bermain balok anak rendah yang diberikan model pembelajaran BCCT, secara teoretik skor minimum yang dicapai adalah 18 dan skor maksimum adalah 72. Berdasarkan kreativitas bermain balok anak yang diujikan kepada 11 anak dengan kemandirian rendah yang diberikan model pembelajaran BCCT diperoleh skor maksimum 45, skor minimum 38, rata-rata hitung 41,36, standar deviasi 2,11; dan varians 4,45. Dari skor maksimum dan minimum tersebut, diperoleh rentangan skor 7, interval kelas 2 dan banyaknya kelas 4 . Dari data tersebut dapat ditampilkan dalam bentuk tabel berikut ini:

Tabel

Deskripsi Data $\mathrm{A}_{1} \mathrm{~B}_{2}$

\begin{tabular}{|c|l|l|l|l|l|c|}
\hline $\begin{array}{c}\text { Data } \\
\text { Variabel }\end{array}$ & $\begin{array}{l}\text { S } \\
\text { ko } \\
\text { r } \\
\text { M } \\
\text { in }\end{array}$ & Maks & $\begin{array}{l}\text { Ran } \\
\text { ge }\end{array}$ & Mean & S & $\mathrm{S}^{2}$ \\
\hline $\mathrm{A}_{1} \mathrm{~B}_{2}$ & 38 & 45 & 7 & 41,36 & $\begin{array}{l}2,1 \\
1\end{array}$ & $\begin{array}{l}4,4 \\
5\end{array}$ \\
\hline
\end{tabular}


Dengan data tersebut, dapat dibuat tabel distribusi frekuensi, seperti tampak pada Tabel 17.

Tabel

Disribusi Frekuensi Skor Kreativitas bermain balok anak Rendah yang Diberikan Model pembelajaran BCCT

\begin{tabular}{|c|c|c|c|c|c|}
\hline Kelas & Batas Kelas & \multicolumn{4}{|c|}{ Frekuensi } \\
\cline { 3 - 6 } Interval & & Absolut & Komulatif (S) & Relatif (\%) & Relatif-Kum \\
\hline $38-39$ & $37.5-39.5$ & 2 & 2 & 18.2 & 18.2 \\
$40-41$ & $39.5-41.5$ & 4 & 6 & 36.4 & 54.5 \\
$42-43$ & $41.5-43.5$ & 3 & 9 & 27.3 & 81.8 \\
$44-45$ & $43.5-45.5$ & 2 & 11 & 18.2 & 100.0 \\
\hline Jumlah & & 11 & & 100 & \\
\hline
\end{tabular}

Agar lebih jelas maka dibuat histogram sebagai berikut :

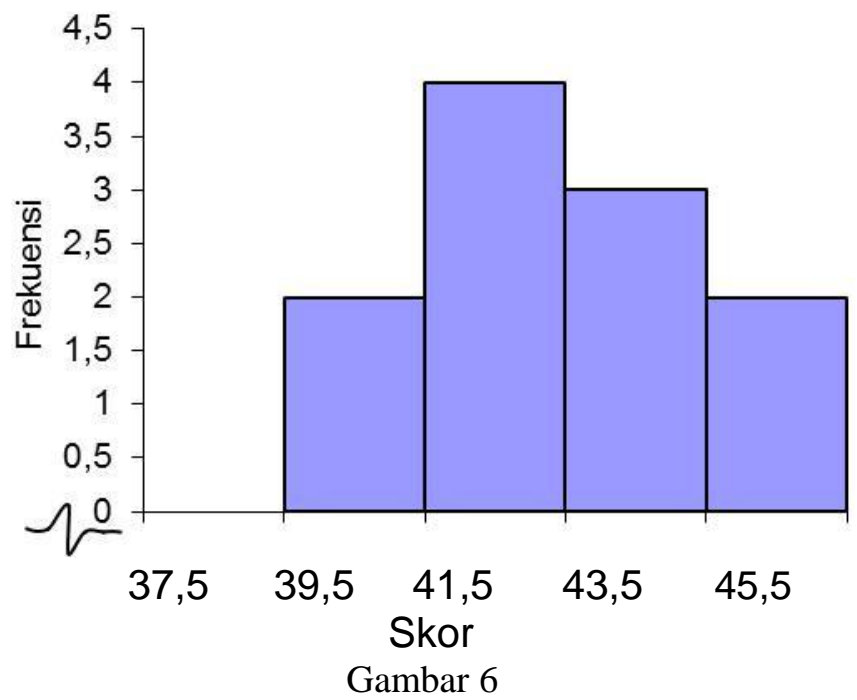

Histogram Skor Kreativitas bermain balok Anak dengan Kemandirian Rendah yang Diberikan Model pembelajaran BCCT

7. Kreativitas bermain balok dengan Metode KONVENSIONAL dan Kemandirian Tinggi $\left(\mathrm{A}_{2} \mathrm{~B}_{1}\right)$

Data kreativitas bermain balok anak dengan model pembelajaran konvensional yang memiliki kemandirian tinggi, secara teoretik skor minimum yang dicapai adalah 18 dan skor maksimum adalah 72. Berdasarkan tes kreativitas bermain balok anak yang diujikan kepada 11 orang yang diberikan model pembelajaran konvensional dengan kemandirian tinggi, diperoleh skor maksimum 44, skor minimum 37, rata-rata hitung 40,18, standar deviasi 2,44, dan varians 5,96. Dari skor maksimum dan minimum tersebut, diperoleh rentangan skor 7, interval kelas 2 dan banyaknya kelas 4 . Dari data tersebut dapat ditampilkan dalam bentuk tabel berikut ini: 
Tabel

Deskripsi Data $\mathrm{A}_{2} \mathrm{~B}_{1}$

\begin{tabular}{|c|c|c|c|c|c|c|}
\hline Data & $\mathrm{S}$ & & & & & \\
\hline Variabel & $\begin{array}{l}\text { ko } \\
\text { r } \\
\text { M } \\
\text { in }\end{array}$ & $\begin{array}{l}\text { Skor } \\
\text { Maks }\end{array}$ & $\begin{array}{l}\text { Ran } \\
\text { ge }\end{array}$ & $\begin{array}{l}\text { Mea } \\
\mathrm{n}\end{array}$ & $S$ & $S^{2}$ \\
\hline $\mathrm{A}_{2} \mathrm{~B}_{1}$ & 37 & 44 & 7 & $\begin{array}{l}40,1 \\
8\end{array}$ & $\begin{array}{l}2,4 \\
4\end{array}$ & $\begin{array}{l}5,9 \\
6\end{array}$ \\
\hline
\end{tabular}

Dengan data tersebut, dapat dibuat tabel distribusi frekuensi, seperti tampak pada Tabel 19. Tabel

Disribusi Frekuensi Skor Kreativitas bermain balok Diberikan Model pembelajaran konvensional yang memiliki Kemandirian Tinggi

\begin{tabular}{|c|c|c|c|c|c|}
\hline Kelas & Batas Kelas & \multicolumn{4}{|c|}{ Frekuensi } \\
\cline { 3 - 6 } Interval & & Absolut & Komulatif (S) & Relatif (\%) & Relatif-Kum \\
\hline $37-38$ & $36.5-38.5$ & 3 & 3 & 27.3 & 27.3 \\
$39-40$ & $38.5-40.5$ & 3 & 6 & 27.3 & 54.5 \\
$41-42$ & $40.5-42.5$ & 2 & 8 & 18.2 & 72.7 \\
$43-44$ & $42.5-44.5$ & 3 & 11 & 27.3 & 100.0 \\
\hline Jumlah & & 11 & & 100 & \\
\hline
\end{tabular}

Agar lebih jelas maka dibuat histogram sebagai berikut :

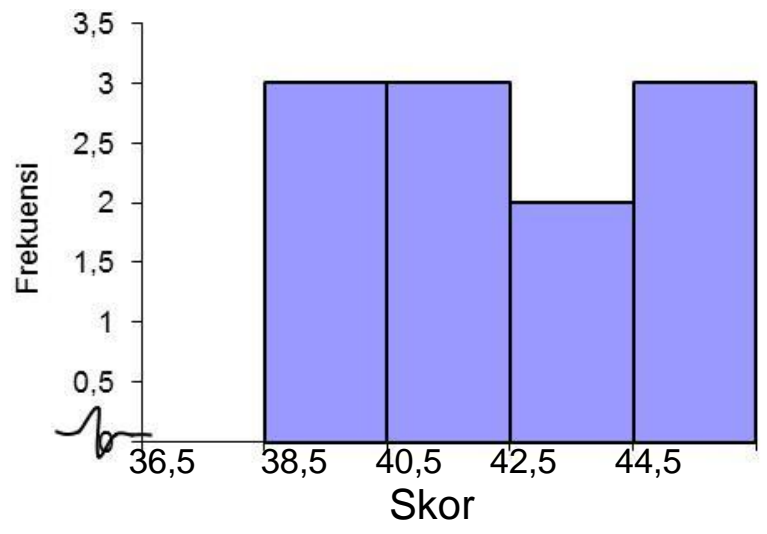

Gambar 7

Histogram Skor Kreativitas bermain balok dengan Model pembelajaran konvensional yang memiliki kemandirian tinggi

\section{Kreativitas bermain balok yang diberikan Model pembelajaran konvensional dengan}

\section{Kemandirian Rendah (A2 $\left.\mathrm{B}_{2}\right)$}

Data kreativitas bermain balok anak yang diberikan model pembelajaran konvensional dengan kemandirian rendah, secara teoretik skor minimum yang dicapai adalah 18 dan skor maksimum adalah 72. Berdasarkan tes kreativitas bermain balok anak yang diujikan kepada 11 orang yang 
diberikan model pembelajaran konvensional dengan kemandirian rendah, diperoleh skor maksimum 51, skor minimum 44, rata-rata hitung 47,45, standar deviasi 2,07; dan varians 4,27; Dari skor maksimum dan minimum tersebut, diperoleh rentangan skor 7, interval kelas 2 dan banyaknya kelas 4. Dari data tersebut dapat ditampilkan dalam bentuk tabel berikut ini:

Tabel

Deskripsi Data $\mathrm{A}_{2} \mathrm{~B}_{2}$

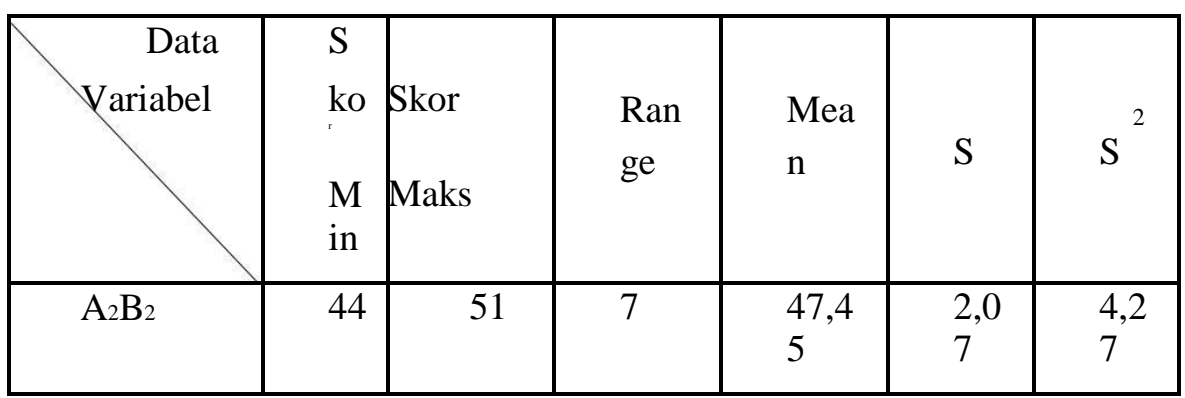

Dengan data tersebut, dapat dibuat tabel distribusi frekuensi, seperti tampak pada Tabel 21.

Tabel

Distribusi Frekuensi Skor Kreativitas bermain balok Anak dengan Kemandirian Rendah yang Diberikan Model Pembelajaran Konvensional

\begin{tabular}{|c|c|c|c|c|c|}
\hline Kelas & Batas Kelas & \multicolumn{4}{|c|}{ Frekuensi } \\
\cline { 3 - 6 } Interval & & Absolut & Komulatif (S) & Relatif (\%) & Relatif-Kum \\
\hline $44-45$ & $43.5-45.5$ & 2 & 2 & 18.2 & 18.2 \\
$46-47$ & $45.5-47.5$ & 4 & 6 & 36.4 & 54.5 \\
$48-49$ & $47.5-49.5$ & 3 & 9 & 27.3 & 81.8 \\
$50-51$ & $49.5-47.5$ & 2 & 11 & 18.2 & 100.0 \\
\hline Jumlah & & 11 & & 100 & \\
\hline
\end{tabular}

Agar lebih jelas maka dibuat histogram sebagai berikut :

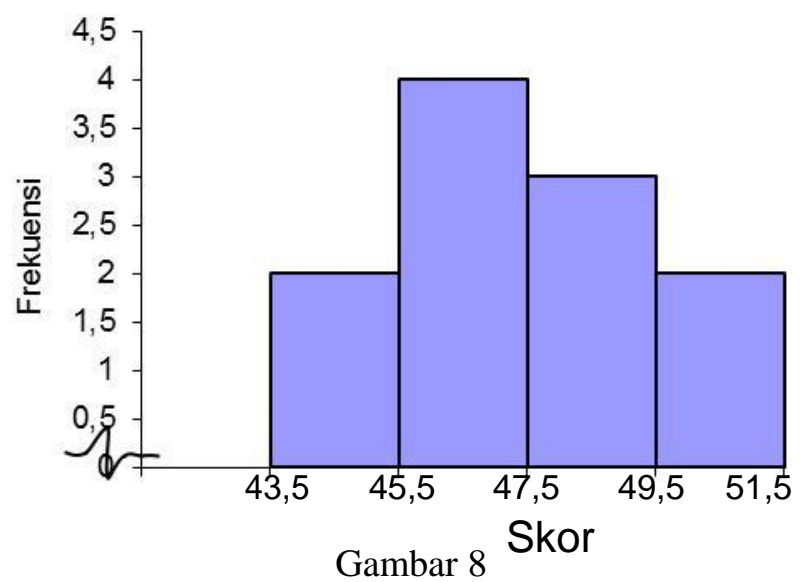

Histogram Skor Kreativitas bermain balok anak yang Diberikan Model pembelajaran konvensional dengan Kemandirian Rendah 
Pembahasan hasil pengujian hipotesis penelitian lebih lanjut adalah sebagai berikut:

\section{Hipotesis Pertama}

Model pembelajaran BCCT suatu model pembelajaran pada anak TK dimana anak dapat belajar berdasarkan tingkatan minat yang diinginkannya dengan cara berkumpul melingkar bersama dengan teman dan guru-guru. Anak yang berminat pada IPA maka dapat bermain pada sentra IPA, anak yang senang bermain balok dapat bermain pada sentra balok dan seterusnya. Adanya pengelompokkan ini membuat anak lebih terfokus pada kegiatan yang diinginkannya. Sehingga kemampuan dan kreativitasnya pada bidang tersebut akan lebih tereksplorasi..

Berbeda dengan metode konvensional, anak tidak terfokus pada kegiatan yang menjadi minatnya. Anak tidak bisa fokus pada kegiatan yang menjadi minatnya. Sehingga anak kurang tergali kreativitasnya pada satu bidang.

\section{Hipotesis Kedua}

Anak yang memiliki kemandirian tinggi yang diberikan model pembelajaran BCCT menujukan kreativitas bermain balok yang lebih besar daripada anak yang diberikan model pembelajaran

konvensional. Sebaliknya, anak yang memiliki kemandirian rendah yang diberikan model pembelajaran BCCT menunjukkan kreativitas bermain balok yang lebih kecil daripada anak yang diberikan model pembelajaran konvensional. Hal ini menunjukkan bahwa dalam memberikan model pembelajaran yang tepat harus memperhatikan kemandirian anak.

\section{Hipotesis Ketiga}

Anak yang telah memiliki kemandirian tinggi memiliki kreativitas bermain balok yang baik. Sehingga jika ditambah lagi dengan faktor eksternal yakni guru yang mengajarkannya dan model pembelajaran BCCT yang mengarahkan anak belajar berdasarkan minatnya, maka anak yang memiliki kemandirian tinggi akan lebih berhasil lagi dalam meningkatkan kreativitas anak bermain balok.

Sementara anak yang memiliki kemandirian rendah perlu dibantu oleh faktor eksternal yang lebih baik agar anak dapat meningkat kreativitasnya yakni guru dan model pembelajaran yang tepat. Pada metode BCCT anak dapat mulai belajar berdasarkan minat yang diinginkannya. Ketika ia ingin bermain balok, maka anak dapat masuk ke sentra bermain balok, ditambah dengan model BCCT di mana anak berkumpul bersama teman-temannya dan guru dalam suatu .lingkaran.

\section{Hipotesis Keempat}

Anak yang memiliki kemandirian rendah akan lebih terbantu dengan model pembelajaran konvensional. Karena anak dengan kemandirian rendah ingin selalu dibantu oleh teman atau gurunya ketika ia melakukan sesuatu. Sehingga anak dengan kemandirian rendah lebih tepat menggunakan metode konvensional dibandingkan dengan model pembelajaran BCCT.

\section{KESIMPULAN}

Penelitian ini mengkaji pengaruh model pembelajaran dan kemandirian terhadap kreativitas anak usia dini pada TAAM Nurul Hidayah, Model pembelajaran yang diberikan berupa model pembelajaran BCCT dan model pembelajaran konvensional.

Berdasarkan hasil uji hipotesis yang telah diuraikan pada bab sebelumnya, dapat ditarik kesimpulan sebagai berikut: (1) kreativitas anak yang diberi model pembelajaran BCCT lebih tinggi daripada anak yang diberi model pembelajaran konvensional. Dari gambaran ini dapat dikatakan bahwa untuk meningkatkan kreativitas anak usia dini dapat digunakan model pembelajaran BCCT; (2) Terdapat interaksi antara model pembelajaran dan kemandirian terhadap kreativitas bermain balok anak usia dini.

(3) Kreativitas anak yang diberi model pembelajaran BCCT pada kelompok siswa yang memiliki kemandirian tinggi lebih tinggi daripada kelompok siswa yang diberi model pembelajaran konvensional. Dengan demikian untuk meningkatkan kreativitas anak usia dini yang memiliki kemandirian tinggi dapat 
menggunakan model pembelajaran BCCT; (4) Kreativitas anak yang diberi model pembelajaran konvensional pada kelompok siswa kemandirian rendah lebih tinggi daripada kelompok siswa yang diberi model pembelajaran BCCT. Dengan demikian untuk meningkatkan kreativitas anak usia dini yang memiliki kemandirian rendah dapat digunakan model pembelajaran konvensional; Dapat disimpulkan bahwa untuk meningkatkan kreativitas bermain balok anak usia dini dapat menggunakan model pembelajaran berupa model pembelajaran BCCT dan model pembelajaran konvensional.

\section{DAFTAR PUSTAKA}

Alisjahbana, Sultan Takdir. Kreativitas. Jakarta, Dian Rakyat, 1983.

Anastasi, Anne dan S. Urbina. Psychology Testing. New York: Prentice Hall International, 1997.

Anon, Creative: Play Helps Children Grow (www.nnc.org)

Anon. Program Kegiatan Belajar (Kurikulum) Kelompok Bermain. Jakarta: Depdiknas, 2001.

Arikunto, Suharsimi. Prosedur Penelitian suatu Pendekatan. Jakarta: Rineka Cipta, 1996.

Aschner, Mary Jane dan Charles E. Bish. Productive Thinking in Education. Washington DC: National Educational Association, 1968.

Bean, Reinold. Cara Mengembangkan Kreativitas Anak, terjemahan Med. Meitasari Tjandrasa. Jakarta, Erlangga, 1995.

Bloomberg, Marton. Theory and Research. New Haven: Collage and University Press, 1973.

Day, Barbara D. Early Childhood Education Development Experiental Teaching on Learning. USA: MacMillan College, 1991.

Devito,Alfred et.al., Creative Teaching: A Practical Approach. London: Haper Collins Colegge Publisher, 1993.

Direktorat PAUD-Dirjen PLS \& Pemuda. Modul Pembuatan dan Penggunaan APE (Alat Permainan Edukatif) Anak Usia 3-6 tahun. Jakarta: Departemen Pendidikan Nasional, 2003.

Docket, Sue; Marilyn Fleer. Play and Pedagogy in Early Childhood Bending The Rules. Australia Thomson Learning, 2002.

Gilmore, John V. The Productive Puerility. California: Albion Publishing Company, 1974.

Goble, Frank F. Madzhab Ketiga Psikologi Humanistik Abraham Maslow terj. A. Suratinya. Yogyakarta: Kanisius, 1987.

Gorman, Richard M. The Psychology of Classroom Learning in Inductive Approach. Ohio: Charles E. Merrill Publishing Company, 1974.

Hadi, Sutrisno. Statistik. Yogyakarta: Andi, 2001.

Hajar, Ibnu. Dasar-Dasar Metodologi Penelitian Kualitatif. Jakarta: Raja Grafindo Persada, 1999.

Hendrick, Joanne. Total Learning Curriculum for Young Child. London: Merrill Publishing Company, 1986.

Hirsch, Elizabeth S. The Block Book. Washington DC :NAEYC, 1996.

Hurlock, Elizabeth B. Perkembangan Anak jilid I. Jakarta: Erlangga, 1997. . Personality Development. New Delhi: McGraw Hill, 1974.

Isbell, Rebecca. The Complete Learning Center Book. US: Gyrophon House, Inc., 1995.

Isenberg, Joan Packer; Mary Renck Jolonggo. Creative Expression and Play In Early Childhood. New Jersey : Merril Prentice Hall, 2001.

Kurikulum dan Hasil Belajar Pendidikan Anak Usia Dini, (Jakarta : Pusat Balitbang Departemen Pendidikan Nasional, 2002),h.5

Margono, Latri M. Anak-Anak Pengungsi Masih dapat Kreatif Bermain, Studi Tentang Leasure, Makalah untuk Hari Anak Nasional, 2005.

Mc Dowell, http://www.mrsmcdowell.com/centers.htmt/Centerstolnclude..

Moeslichatoen. Metode Pengajaran Di Taman Kanak- Kanak. Jakarta: Rineka Cipta, 1999.

Monks, F.J;. A.M.P. Knoers, Siti Rahayu Haditomo. Psikologi Perkembangan. Yogjakarta : Gajah Mada University Press, 1991.

Mujito. Kemandirian dan Hasil Prestasi Belajar Mahasiswa. Laporan Penelitian, IKIP Padang, 1993. 
